\title{
An update on the distribution of yellow-throated marten Martes flavigula in Nepal
}

\author{
Hari Basnet ${ }^{1 *}$ (I) $\mid$ Anu Rai ${ }^{2}$ (I) \\ ${ }^{1}$ Small Mammals Conservation and Research Foundation (SMCRF), Kathmandu Nepal \\ ${ }^{2}$ The Thin Page Pvt. Ltd., Kathmandu, Nepal \\ *Correspondence: haribasnet88@gmail.com
}

Received: 10 October 2020 | Revised: 17 December 2020 | Accepted: 17 December 2020

\begin{abstract}
The yellow-throated marten Martes flavigula is encountered frequently by many researchers or nature guides but the information remains unavailable to the wider scientific community. The conservation efforts are already stretched thin and the species being Least Concern in the IUCN Red List of Threatened Species points to the reality that a dedicated budget for studying its ecology and distribution will not be readily available. We try to amend this data gap by presenting a non-targeted survey of the yellow-throated marten from May 2013 to January 2020 recorded during the field work in the mid hills and mountains of Nepal. The species was reported from 22 different sites which includes five protected areas of Nepal. Among them, we reported the species for the first time from Dhorpatan Hunting Reserve and districts of Achham, Bajura and Gulmi. We recommend a guideline to be developed for recording the opportunistic sightings and encourage researchers to share their records that will improve understanding of yellow-throated marten distribution in Nepal.
\end{abstract}

Keywords: Mustelidae, Opportunistic sightings, Photographic evidences, Small carnivore, Yellow-throated marten

\section{1 | Introduction}

Yellow-throated marten Martes flavigula is the largest among the old-world martens (Mallick 2013). It is distributed through western Asia and Siberia with widespread distribution in South, Southeast and East Asia (Sathyakumar 1999, Chutipong et al. 2015). The species inhabits tropical rainforests, subtropical foothills and temperate to alpine habitats in the Himalayas (Appel 2013, Appel \& Khatiwada 2014). In Nepal, the species is mainly found below 3,254 m above sea level (asl) and recorded from Annapurna Conservation Area (CA), Chitwan National Park (NP), Khaptad NP, Langtang NP, Makalu Barun NP, Rara NP, Sagarmatha NP and Shuklaphanta NP (Jnawali et al. 2011). Even though, the species is widespread in the Terai region (Jnawali et al. 2011, Lamichhane et al. 2014), Appel and Khatiwada (2014) have recorded the species at an elevation of $4,510 \mathrm{~m}$ in the alpine meadow in the Kanchenjunga $\mathrm{CA}$, the highest elevation record for this species in the world.

Yellow-throated marten is categorized as Least Concern nationally as well as globally (Jnawali et al. 2011, Chutipong et al. 2015) as a result of its widespread distribution with presence in many protected areas, large population, occurrence in many heavily degraded sites and the lack of identification of major threats. However, it has been speculated that some of islandendemic species might be threatened (Chutipong et al. 2015). Even though the population of yellow-throated marten is estimated to be stable, poaching for fur and habitat loss are the major threats to the species in Nepal (Jnawali et al. 2011). Globally, population of the species is declining, however, the species is quite resilient to widespread threats of forest deterioration along with intensive non-selective ground-based traps. Hence, it is deemed unlikely to be declining much more than the background rate of deforestation (Chutipong et al. 2015). Yellow-throated marten is a voracious predator and its diet consists of a wide variety of food ranging from vertebrate, invertebrates, fruits, food waste and even human corpses have been speculated (Pierce et al. 2014, Parr \& Duckworth 2007). In Chitwan NP, the species has been witnessed to carry small Indian civet Viverricula indica, although it was unclear whether it was killed or scavenged (Lamichhane et al. 2014) and insects such as 
wasp (the scat content) (Shrestha \& Basnet 2005). Despite its widespread distribution in Nepal, relatively little is known about its distribution, ecology and behavior, particularly in its tropical range (Lamichhane et al. 2014), or rugged landscapes (Appel \& Khatiwada 2014). Although the species is frequently encountered by many researchers or nature guides, this information are not made available to the wider scientific community as opportunistic surveys are not given much importance. We have presented a non-targeted survey of this species during different field visits in Nepal and hope that this study aimed at bridging the data gap of the species.

\section{2 | Materials and methods}

Direct sightings of the yellow-throated marten are presented here. These sightings were opportunistically (non-targeted survey) collected from May 2013 to January 2020 during the field work in the mid hills and mountains of Nepal. Date, time and geographic coordinates were gathered from information embedded in the photo details or from reviewing the field notes. In most of the sites, geographical coordinates and elevations were taken from the Garmin Etrex 10. General information of species recorded habitats were noted along with the general behavior of the species.

\section{3 | Results}

Yellow-throated martens were encountered on at least 22 locations in 22 different incidences with 35 individuals from Makalu Barun NP in the east to Achham district in the west (Fig. $1 \&$ Annex 1) in the mid hills and mountains of Nepal. Of those 35 sightings, twelve sightings were recorded singly, seven sightings in duos while groups of three were recorded in three sightings. We recorded species from an elevation of $885 \mathrm{~m}$ in Kaski district to $3,504 \mathrm{~m}$ in the Khumbupasanglahmu Rural Municipality (RM) inside the Sagarmatha NP. Among all the sightings, eight sightings were within the protected areas (4locations in Annapurna CA, 1-Dhorpatan Hunting Reserve, 1Makalu Barun NP, 1- Sagarmatha NP and 2-Shivapuri Nagarjun NP). Moreover, six sites were located within the Kathmandu valley, mostly in the southern hills of Kathmandu district.

The species was reported for the first time from Gulmi, Bajura and Achham district and Dhorpatan Hunting Reserve. The species was recorded in diverse habitats; shrubby areas, human dominated landscapes, dense forest, abandoned land as well as

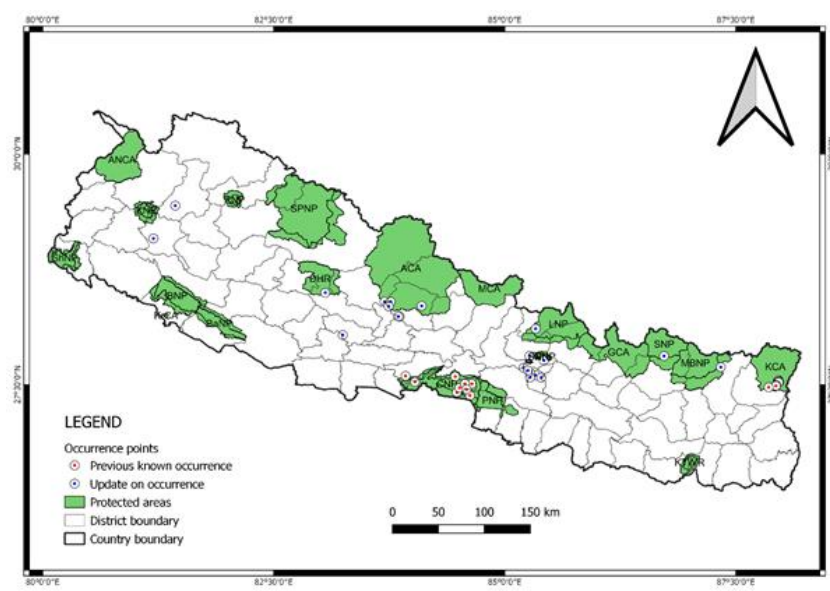

Figure 1. The occurrence of Yellow-throated Marten in Nepal. Previous known occurrences obtained from Appel and Khatiwada (2014) and Lamichhane et al. (2014)

riverine belts. In Bhotkhola Rural Municipality (RM) of Sankhuwasabha district and Kakani Municipality, the species was found feeding on the fruiting trees of Gagun Saurauia napaulensis while in Madi RM, two individuals were seen chasing the Indian hare Lepus nigricollis though whether the hare was caught or not was not determined.

The activity density functions revealed that yellow-throated marten activities start in the morning and evening with major activities peak occurring at $09 \mathrm{~h} 00$ to $10 \mathrm{~h} 00$ but considerably drop in the afternoon to peak again in evening between $17 \mathrm{~h} 30$ to 18 h30 (Fig. 2).

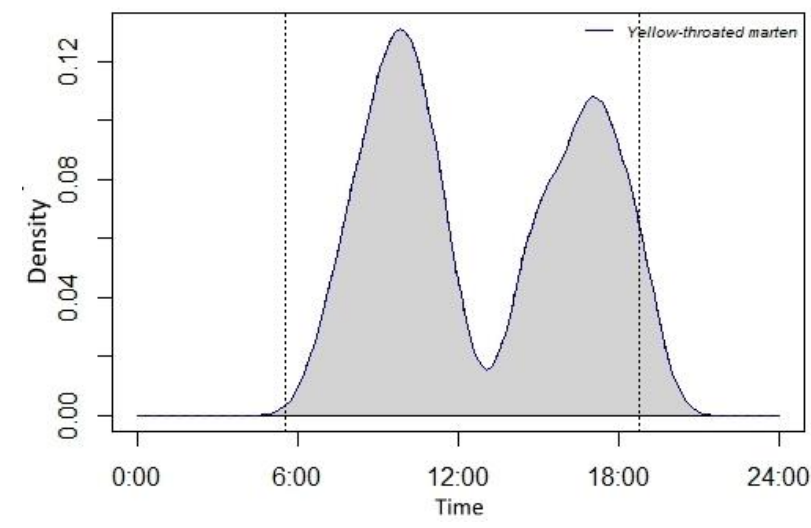

Figure 2. Estimated activity patterns for yellow-throated marten species

\section{4 | Discussion}

Our opportunistic sightings with proper documentation will improve understanding of yellow-throated marten distribution and will be helpful in reassessment of conservation status of the species in future. Even though such data have flaws with regards to unequal sampling effort, this information can be vital for 
updating the distribution of the species (Okes \& Riain 2019). We believe that our sighting will be helpful for wildlife managers to minimize the conflict caused by the species as it is renowned as a chicken depredator in many parts of rural villages in Nepal. Grassman et al. (2005) reported no previous ecological study of the species and its diet remains little-studied or based on opportunistic observations. Our two sightings on the feeding on the fruits of Saurauia napaulensis plant added a new plant-based diet of the species. Of the 18 sightings of the species in Namdapha Tiger Reserve, $50 \%$ of the sighting were witnessed while feeding on the fig plants and/or while lurking to nab frugivorous birds visiting the fig plants (Naniwadekar et al. 2013). Moreover, the species is generally considered to be voracious predators (Pierce et al. 2014), and our observation on chasing Indian hare supports the fact that it feeds a wide variety of wild animals. In western part of Nepal, the yellow-throated marten was seen in the cheer pheasant Catreus wallichii habitat and it is one of the main natural predators of cheer pheasant threatening its survival (Basnet 2016).

\section{5 | Conclusions}

Present study has provided an update on the distribution of yellow-throated marten in Nepal. The study presents the first recordings from Achham, Bajura and Gulmi districts and Dhorpatan Hunting Reserve. This opportunistic sighting can provide important information on the species presence and further ecological studies are recommended. The opportunistic sighting data has its flaws yet they can provide reliable information and broaden the scope of ecological inquiries. Therefore, recording habitat type, general behavior, GPS location, elevation, date and time are highly recommended as such information can provide low-cost information about the spatio-temporal distribution of the species.

\section{Acknowledgements}

We are thankful to Small Mammals Conservation and Research Foundation for providing the opportunity to conduct different field work in Nepal.

\section{Authors' contributions}

Basnet, H. collected the primary data; Rai, A. conducted literature review and both the authors contributed in the preparation of the manuscript and gave final approval for publication.

\section{Conflicts of interest}

Authors declare no conflict of interest.

\section{ORCID}

Hari Basnet (D) https://orcid.org/0000-0003-4179-8074

Anu Rai (D) https://orcid.org/0000-0002-8778-9571

\section{References}

Appel, A. 2013. Small carnivores in the Annapurna Conservation Area, Nepal. Vertebrate Zoology 63:111-121.

Appel, A. and Khatiwada, A. P. 2014. Yellow-throated martens Martes flavigula in the Kanchenjunga Conservation Area, Nepal. Small Carnivore Conservation, 50:14-19.

Basnet, H. 2016. Survey of cheer pheasant Catreus wallichii in Bajura District, Nepal. A report submitted to Oriental Bird Club, UK, $p$ 23.

Chutipong, W., Duckworth, J. W., Timmins, R. J., Choudhury, A., Abramov, A. V., Roberton, S., et al. 2015. Martes flavigula, yellow-throated Marten. A report submitted to the The IUCN Red List of Threatened Species: e.T41649A45212973

Grassman, L. I., Tewes, M. E. and Silvy, N. J. 2005. Ranging, habitat use and activity patterns of binturong Arctictis binturong and yellow-throated marten Martes flavigula in north-central Thailand. Wildlife Biology 11:49-57.

https://doi.org/10.2981/0909-6396(2005)11[49:RHUAAP]2.0.CO;2

Jnawali, S. R., Baral, H., Lee, S., Acharya, K., Upadhyay, G., Pandey, M., et al. 2011. The status of Nepal mammals: The National Red List Series. A report submitted to the Department of National Parks and Wildlife Conservation, Kathmandu, Nepal.

Lamichhane, B. R., Pokheral, C. P., Khatiwada, A. P., Mishra, R. and Subedi, N. 2014. A yellow-throated Marten Martes flavigula carrying a small Indian civet Viverricula indica. Small Carnivore Conservation 51:46-50.

Mallick, J. K. 2013. Himalayan yellow-throated marten (Martes flavigula) in West Bengal, India. Taprobanica 5:89-93.

Naniwadekar, R., Shukla, U., Viswanathan, A. and Datta, A. 2013. Records of small carnivores from in and around Namdapha Tiger Reserve, Arunachal Pradesh, India. Small Carnivore Conservation 49:1-8.

Okes, N. C. and O'Riain, M. J. 2019. Can opportunistic citizen sightings assist in the monitoring of an elusive, crepuscular mammal in an urban environment? Urban Ecosystems 22:483-492. https://doi.org/10.1007/s11252-019-0829-3 
Parr, J. and Duckworth, J. W. 2007. Notes on diet, habituation and sociality of yellow-throated marten Martes flavigula. Small Carnivore Conservation 36:27-29.

Pierce, A. J., Sukumal, N. and Khamcha, D. 2014. A yellow-throated marten Martes flavigula feeding on a red muntjac Muntiacus muntjak carcass. Small Carnivore Conservation 51:76-78.

Sathyakumar, S. 1999. Mustelids and viverrids of the northwestern and western Himalayas. Envis Bulletin Wildlife and Protected Areas 2(2):39-42.

Shrestha, B. and Basnet, K. 2005. Indirect methods of identifying mammals: a case study from Shivapuri National Park, Nepal. Ecoprint: An International Journal of Ecology 12:43-57. https://doi.org/10.3126/eco.v12i0.3196

\section{Cite this article as:}

Basnet, H. and Rai, A. 2020. An update on the distribution of yellowthroated marten Martes flavigula in Nepal. Nepalese Journal of Zoology 4(2):147-151. https://doi.org/10.3126/njz.v4i2.33907 
Annex 1. Records of yellow-throated marten Martes flavigula in various parts of Nepal with dates, time, elevation, habitat and coordinates from north to south. Note: M- municipality; RM- Rural Municipality

\begin{tabular}{|c|c|c|c|c|c|c|c|c|}
\hline S.N & Location & $\begin{array}{l}\text { Latitude } \\
\mathrm{N}\end{array}$ & $\begin{array}{l}\text { Longitude } \\
\text { E }\end{array}$ & Elevation & Date & Time & Record type & Habitat \\
\hline 1 & $\begin{array}{l}\text { Godawari M } \\
\text { (Lalitpur) }\end{array}$ & 27.6040 & 85.3315 & 1,444 & 4-Feb-2017 & $09 \mathrm{~h} 27$ & $\begin{array}{l}\text { Direct } \\
\text { Observation, } \\
\text { photograph }\end{array}$ & $\begin{array}{l}\text { vegetation dominated by Castanopsis indica, } \\
\text { Choerospondias axillaris (Lapsi), Ficus sp., Myrica } \\
\text { esculenta, Prunus cersoides, P. paschia (Mayal), Oak } \\
\text { Quercus glauca (Sano falant), Schima wallichi etc. }\end{array}$ \\
\hline 2 & $\begin{array}{l}\text { Chandragiri M } \\
\text { (Kathmandu) }\end{array}$ & 27.6848 & 85.2045 & 1,695 & 2-Jul-2014 & $18 \mathrm{~h} 37$ & $\begin{array}{l}\text { Direct } \\
\text { Observation }\end{array}$ & Schima wallichii Forest \\
\hline 3 & Madi RM (Kaski) & 28.3547 & 84.1008 & 1,945 & 13-Mar-2016 & 09h54 & $\begin{array}{l}\text { Direct } \\
\text { Observation }\end{array}$ & $\begin{array}{l}\text { Shrubland/grassland above the Sikles village, } \\
\text { chasing the Indian hare (probably) }\end{array}$ \\
\hline 5 & $\begin{array}{l}\text { Gokarneshwor M } \\
\text { (Kathmandu) }\end{array}$ & 27.7634 & 85.4236 & 1,416 & 16-Jan-2016 & $09 h 49$ & $\begin{array}{l}\text { Direct } \\
\text { observation/ } \\
\text { photograph }\end{array}$ & Abandoned land \\
\hline 6 & $\begin{array}{l}\text { Dakshinkali M } \\
\text { (Kathmandu) }\end{array}$ & 27.6269 & 85.2772 & 1,753 & 16-Dec-2016 & $15 \mathrm{~h} 13$ & $\begin{array}{l}\text { Direct } \\
\text { Observation }\end{array}$ & Pine dominated Forest \\
\hline 7 & $\begin{array}{l}\text { Dakshinkali M } \\
\text { (Kathmandu) }\end{array}$ & 27.5805 & 85.2742 & 1,208 & 13-Apr-2017 & $11 \mathrm{~h} 19$ & $\begin{array}{l}\text { Direct } \\
\text { Observation }\end{array}$ & Bank of Bagmati River \\
\hline 8 & $\begin{array}{l}\text { Badimalika RM } \\
\text { (Bajura) }\end{array}$ & 29.4400 & 81.4352 & 1,820 & 16-May-2016 & 17h51 & $\begin{array}{l}\text { Direct } \\
\text { observation/ } \\
\text { photograph }\end{array}$ & Pine Forest \\
\hline 9 & $\begin{array}{l}\text { Gosaikunda RM } \\
\text { (Rasuwa) }\end{array}$ & 28.1070 & 85.3346 & 2,936 & 10-Dec-2014 & $15 \mathrm{~h} 20$ & $\begin{array}{l}\text { Direct } \\
\text { observation/ } \\
\text { photograph }\end{array}$ & Abandoned Farmland \\
\hline 10 & $\begin{array}{l}\text { Khumbupasanglah } \\
\text { mu RM } \\
\text { (Solukhumbu) }\end{array}$ & 27.8112 & 86.7237 & 3,504 & 15-Oct-2015 & $10 \mathrm{~h} 27$ & $\begin{array}{l}\text { Direct } \\
\text { observation/ } \\
\text { photograph }\end{array}$ & Rocky area \\
\hline 11 & $\begin{array}{l}\text { Annapurna RM } \\
\text { (Myagdi) }\end{array}$ & 28.4007 & 83.6998 & 2,858 & $\begin{array}{l}-17 \text { Aug- } \\
2016\end{array}$ & $14 \mathrm{~h} 29$ & $\begin{array}{l}\text { Direct } \\
\text { Observation }\end{array}$ & $\begin{array}{l}\text { Rhododendron, Black Juniper, Spurce, } \\
\text { Deodar }\end{array}$ \\
\hline 12 & $\begin{array}{l}\text { Annapurna RM } \\
\text { (Kaski) }\end{array}$ & 28.3987 & 83.7660 & 2,668 & 19-Dec-2016 & $17 \mathrm{~h} 17$ & $\begin{array}{l}\text { Direct } \\
\text { observation/ } \\
\text { dead }\end{array}$ & Black Juniper, Blue Pine, Spurce, Deodar \\
\hline 13 & $\begin{array}{l}\text { Annapurna RM } \\
\text { (kaski) }\end{array}$ & 28.3503 & 83.7430 & 1,524 & 31-Jan-2015 & 07h16 & $\begin{array}{l}\text { Direct } \\
\text { observation }\end{array}$ & Abandoned farmland, shrubby area \\
\hline 14 & $\begin{array}{l}\text { Chandragiri } \\
\text { Municipality } \\
\text { (Kathmandu) }\end{array}$ & 27.6552 & 85.2510 & 1,630 & 10-Feb-2018 & $10 h 16$ & $\begin{array}{l}\text { Direct } \\
\text { observation }\end{array}$ & Pine Forest with shrubland \\
\hline 15 & $\begin{array}{l}\text { Resunga } \\
\text { Municipality } \\
\text { (Gulmi) }\end{array}$ & 28.0400 & 83.2472 & 1,490 & 8-Dec-2016 & $16 \mathrm{~h} 43$ & $\begin{array}{l}\text { Direct } \\
\text { observation }\end{array}$ & Farmland \\
\hline 16 & $\begin{array}{l}\text { Kakani M } \\
\text { (Nuwakot) }\end{array}$ & 27.8136 & 85.2674 & 2,050 & 15-Sep-2017 & $08 \mathrm{~h} 06$ & $\begin{array}{l}\text { Direct } \\
\text { observation }\end{array}$ & Feeding on unknown fruits nearby Human settlement \\
\hline 17 & $\begin{array}{l}\text { Bhotkhola RM } \\
\text { (Sankhuwasawa) }\end{array}$ & 27.6915 & 87.3378 & 1,967 & 7-Nov-2019 & $17 \mathrm{~h} 05$ & $\begin{array}{l}\text { Direct } \\
\text { observation/ } \\
\text { photograph }\end{array}$ & Mixed forest, feeding on fruits \\
\hline 18 & Dhorpatan RM & 28.4974 & 83.0578 & 3,105 & 8-May-2013 & $18 \mathrm{~h} 38$ & $\begin{array}{l}\text { Direct } \\
\text { observation }\end{array}$ & Scattered dwarf pine forest \\
\hline 19 & $\begin{array}{l}\text { Pokhara Lekhnath } \\
\text { MC }\end{array}$ & 28.2388 & 83.8621 & 855 & 3-Jan-2020 & $11 \mathrm{~h} 26$ & $\begin{array}{l}\text { Direct } \\
\text { observation/ } \\
\text { photograph }\end{array}$ & Small stream nearby human settlement \\
\hline 20 & $\begin{array}{l}\text { Pokhara Lekhnath } \\
\text { MC }\end{array}$ & 28.2391 & 83.8485 & 995 & 4-Jan-2020 & $08 \mathrm{~h} 23$ & $\begin{array}{l}\text { Direct } \\
\text { observation }\end{array}$ & Farmland \\
\hline 21 & $\begin{array}{l}\text { Godawari M } \\
\text { (Lalitpur) }\end{array}$ & 27.5779 & 85.3955 & 2,283 & 21-Apr-2018 & $9 h 14$ & $\begin{array}{l}\text { Direct } \\
\text { observation/ } \\
\text { photograph }\end{array}$ & Oak and Quercus forest \\
\hline 22 & $\begin{array}{l}\text { Mangalsen M } \\
\text { (Achham) }\end{array}$ & 29.0854 & 81.1986 & 1,915 & 23-May-2014 & $16 \mathrm{~h} 23$ & $\begin{array}{l}\text { Direct } \\
\text { observation }\end{array}$ & Pine dominated Forest \\
\hline
\end{tabular}

